\title{
Effect of TNF- $\alpha$ on LH and IGF-I modulated chicken granulosa cell proliferation and progesterone production during follicular development
}

\author{
O. M. Onagbesan*, J. Mast, B. Goddeeris and E. Decuypere \\ Laboratory for Physiology and Immunology of Domestic Animals, Catholic University of Leuven, \\ Kardinaal Mercierlaan 92, B-3001 Heverlee, Belgium
}

\begin{abstract}
This study demonstrates the effects of recombinant human tumour necrosis factor $\alpha$ (rhTNF- $\alpha$ ) and conditioned medium of the HD11-transformed chicken macrophage cell line on cultured chicken granulosa cells. Effects were studied on basal, IGF-I- and LH-stimulated progesterone production and cell proliferation. Recombinant human TNF- $\alpha$ stimulated basal progesterone production in a dose-dependent manner in the granulosa cells of the largest follicle but had no effect on cells from the third largest follicle. TNF- $\alpha$ stimulated and sometimes inhibited progesterone production stimulated by IGF-I and LH alone or in combination depending on the size of the follicle and the concentration of LH or IGF-I applied. However, the inhibitory effect of TNF- $\alpha$ was significantly more pronounced in cells from the third largest follicle when high concentrations of IGF-I, LH or a combination of both were applied. TNF- $\alpha$ had no effect on basal cell proliferation in both the largest and the third largest follicles, but regulated responses to IGF-I and a combination IGF-I and LH in the cells of the third largest follicle but not those of the largest follicle. The data indicate that the normal hierarchy of follicles is maintained in the chicken ovary through the regulation of the activity of IGFI and its interaction with LH. Conditioned medium of LPS-activated HD11 macrophages mimicked the effects of TNF- $\alpha$ and its interaction with IGF-I and LH on progesterone production and cell proliferation. The observation that the HD11conditioned medium contained TNF- $\alpha$ indicates that TNF- $\alpha$ produced by macrophages found in chicken follicles modulates granulosa cell growth and differentiation.
\end{abstract}

\section{Introduction}

Tumour necrosis factor $\alpha(\mathrm{TNF}-\alpha)$ is a $17 \mathrm{kDa}$ protein produced by both mammalian and avian macrophages when activated with lipopolysaccharides (LPS). This protein and its mRNA have also been localized in ovarian granulosa, theca and luteal cells of several mammalian species (Roby et al., 1990; Wuttke et al., 1993; Kondo et al., 1995; Terranova et al., 1995; Shaw and Britt, 1995). Evidence indicates that although ovarian cells are a source of TNF- $\alpha$ in the ovary, local macrophages are the principal source (Bagavandoss et al., 1988; Adashi, 1990; Wang et al., 1992; Zhao et al., 1998).

Several studies have shown that TNF- $\alpha$ has a role in mammalian ovarian follicular development, steroidogenesis, ovulation, luteolysis and atresia. In bovine, human and rat granulosa cells, TNF- $\alpha$ inhibits IGF-I- or gonadotrophinstimulated oestrogen production but either increases or inhibits progesterone production depending on the stage of development of the follicle (Roby and Terranova, 1988; Montgomery Rice et al., 1998, 1999; Spicer, 1998). TNF- $\alpha$ also

${ }^{*}$ Correspondence address: IRS, University of Wales Aberystwyth SY23 3AL. Received 10 January 2000. inhibits IGF-I- or LH-stimulated androgen production (Andreani et al., 1991; Zachow et al., 1993; Zachow and Terranova, 1994; Acosta et al., 1998). TNF- $\alpha$ stimulates proliferation of human luteal cells, but induces apoptosis in granulosa cells of early antral follicles of rats (Wang et al., 1992; Yan et al., 1993; Kaipia et al., 1996). Spaczynski et al. (1999) reported a stimulatory effect of TNF- $\alpha$ on basal and IGF-I- and FSH-stimulated proliferation of cultured theca interstitial cells of rats injected with oestradiol, whereas Andreani et al. (1991) and Zachow and Terranova (1993) found no effect on theca interstitial cells of hypophysectomized rats. These findings indicate that TNF- $\alpha$ exerts a wide variety of effects depending on the type of cell, stage of development and the physiological environment.

To date, the production of TNF- $\alpha$ and other cytokines in follicular cells of the avian ovary has not been investigated. Barua et al. (1998a,b) demonstrated the presence of macrophages within the theca but not within the granulosa layers of chicken ovarian follicles. The macrophage population in these follicles changes with maturation and the age of the bird, thus indicating a functional relevance of these macrophages in the chicken ovary. The macrophages may be a 
source of TNF- $\alpha$ and other cytokines that influence follicular functions. There are indications that TNF- $\alpha$ may influence chicken follicular growth and atresia. Recombinant human TNF- $\alpha$ (rhTNF- $\alpha$ ) induces apoptosis in the granulosa cells of large white follicles and has a role in follicular atresia (Witty et al., 1996). TNF- $\alpha$ increased intracellular calcium in granulosa cells of chickens without a concomitant increase in progesterone production (Soboloff et al., 1995, 1999). Bryan et al. (1997) showed that $5 \mathrm{ng}$ TNF- $\alpha \mathrm{ml}^{-1}$ had an inhibitory effect on progesterone production by granulosa cells of two lines of chicken, whereas $250 \mathrm{ng} \mathrm{ml}^{-1}$ had either no effect or was stimulatory. These studies were conducted under acute conditions of $3 \mathrm{~h}$ incubations, which may have been responsible for the inconsistent results. There are no reports on the effect of TNF- $\alpha$ on chicken granulosa or theca cell proliferation, or its effects on gonadotrophin-or IGF-Istimulated progesterone production or cell proliferation in cultured cells. The aim of the current study was to investigate the response of cultured granulosa cells of the largest and third largest follicles to rhTNF- $\alpha$ treatment in the presence or absence of LH and IGF-I. Since chicken macrophages present in the follicles are a potential source of TNF- $\alpha$ for autocrine or paracrine regulation of granulosa and theca cell functions, granulosa cells were treated with conditioned media generated from macrophages activated with or without LPS. Progesterone production was quantified in culture medium and the effects on cell proliferation during culture were determined.

\section{Materials and Methods}

\section{Preparation of conditioned medium from the HD11 chicken macrophage cell line}

The avian leukaemia virus (strain MC29) transformed chicken macrophage cell line HD11 (Beug et al., 1979) was used for preparing conditioned medium. The HD11 cells were cultured in Dulbecco's modified Eagle's medium (DMEM) (Sigma, Poole) supplemented with 5\% heatinactivated chicken serum, $2 \mathrm{mmol}$ glutamine $\mathrm{l}^{-1}, 1 \mathrm{mmol}$ sodium pyruvate $1^{-1}$ (Sigma, Poole) and $0.1 \% \quad(\mathrm{v} / \mathrm{v})$ gentamycine (Gibco BRL, Paisley). The cells were seeded at $5 \times 10^{6}$ in $72 \mathrm{~cm}^{2} 200 \mathrm{ml}$ cell culture flasks and incubated at $37^{\circ} \mathrm{C}$ in a humidified atmosphere of $5 \% \mathrm{CO}_{2}$ for $72 \mathrm{~h}$ when cells were just near-confluent. During the culture period, cells were either treated without or with different concentrations of LPS $\left(1.25-20.0 \mu \mathrm{g} \mathrm{ml}^{-1}\right)$ (Sigma) to activate TNF- $\alpha$ secretion into the culture medium. At the end of the culture period, medium was collected, sterilized by filtration through $0.22 \mu \mathrm{m}$ sterile filters (Gelman) and stored at $-20^{\circ} \mathrm{C}$ until used. Activation of the HD11 cells was later assessed by measuring chicken TNF- $\alpha$ in the medium using a commercial ELISA kit for human TNF- $\alpha$ (Eurogenetics, Tessenderlo). The monoclonal antibody in this kit crossreacts with chicken TNF- $\alpha$ as determined by immunohistochemistry (data not shown). The stimulatory effect of LPS on chicken TNF- $\alpha$ production in the medium by the HD11 cells is shown (Fig. 1). Secretion of TNF- $\alpha$ increased with the concentration of LPS and reached a maximum at $5 \mu \mathrm{g}$ LPS $\mathrm{ml}^{-1}$. This dose of

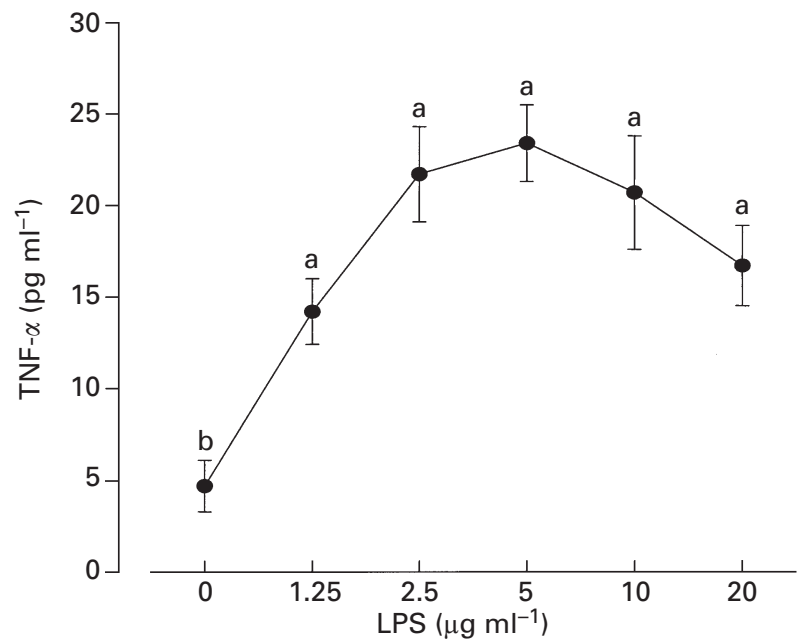

Fig. 1. TNF- $\alpha$ content of medium conditioned with HD11 macrophage cell line activated with increasing doses of lipopolysaccharide (LPS). Cells were cultured for $72 \mathrm{~h}$ in Dulbecco's modified Eagle's medium (DMEM) supplemented with 5\% heat-activated chicken serum. Data points represent means \pm SEM of determinations in medium collected from four separate experiments. Data were analysed by ANOVA and differences compared by Duncan's multiple-range test. Significant differences between means are denoted by different letters $(P<0.05)$.

LPS was subsequently used for generating macrophageconditioned medium designated as MCMWLPS. Conditioned medium generated from HD11 cell cultures without LPS was designated as MCMWOLPS.

\section{Chicken granulosa cell preparation and culture}

Laying ISA Brown hens of 35-45 weeks of age were kept in cages under a photoperiod of $14 \mathrm{~h}$ light:10 h dark. Chickens were provided with food and water ad libitum and laying was monitored each day. Hens were killed by cervical dislocation $12-16 \mathrm{~h}$ after an oviposition. The largest and third largest follicles were excised from the ovary and placed into warmed $\left(37^{\circ} \mathrm{C}\right)$ phenol red-free Hank's balanced salt solution (pfHBSS) (Gibco BRL, Paisley). The granulosa cell layer of the follicles was dissected out as described by Gilbert et al. 1977, and dispersed in $\mathrm{Ca}^{2+}$ - and $\mathrm{Mg}^{2+}$-free Hank's (Sigma) containing $0.1 \mathrm{mg}$ collagenase $\mathrm{ml}^{-1}$ (Sigma) as described by Peddie et al. (1994). Cells from follicles of a similar size were pooled from three to four hens and the cell density was determined by measuring the DNA in aliquots using the method of Labarca and Paigen (1980) in which $1 \mu \mathrm{g}$ DNA = $10^{5}$ cells. Cell viability was assessed using the trypan blue method and was usually $>90 \%$. Cells were resuspended in Medium 199 (M199) (Gibco BRL, Paisley) supplemented with 2 mmol glutamine $\mathrm{l}^{-1}, 40$ mmol sodium bicarbonate $\mathrm{l}^{-1}$, $1 \% \quad(\mathrm{v} / \mathrm{v})$ PSA (antibiotic-antimycotic solution) (Sigma, Poole) and 5\% charcoal-stripped fetal bovine serum (FBS) (Gibco BRL, Paisley) and plated at $0.1 \times 10^{5}$ viable cells per well in 24-well plastic plates (Corning Inc., Corning). Cells were cultured for $48 \mathrm{~h}$ in a humidified atmosphere of $5 \% \mathrm{CO}_{2}$ in air at $37^{\circ} \mathrm{C}$ to establish cultures. After this initial period of 
culture, the medium was discarded and monolayer cells were washed with pfHBSS. The cells were cultured for a further $48 \mathrm{~h}$ in serum-free M199 supplemented with $2 \mathrm{mmol}$ glutamine $1^{-1}, 40 \mathrm{mmol}$ sodium bicarbonate $1^{-1}, 1 \%$ PSA, $6.25 \mu \mathrm{g}$ transferrin $\mathrm{ml}^{-1}, 5 \mathrm{ng}$ selenium $\mathrm{ml}^{-1}$ and $0.1 \%(\mathrm{w} / \mathrm{v})$ BSA (Sigma, Poole). All additions of test hormones and conditioned media were made in the second period of culture for $48 \mathrm{~h}$.

\section{Effect of TNF- $\alpha$ on progesterone production by granulosa cells}

Granulosa cells from the largest and third largest follicles were cultured for 3, 24 and $48 \mathrm{~h}$ in the presence of increasing concentrations $\left(0-100 \mathrm{ng} \mathrm{m}^{-1}\right.$ ) of rhTNF- $\alpha$ (Genentech Inc., San Francisco, CA) to determine the time and dose effect of TNF- $\alpha$. As the effects of rhTNF- $\alpha$ became apparent after $48 \mathrm{~h}$ of incubation (Fig. 2), subsequent tests were conducted under $48 \mathrm{~h}$ incubations. Cells were cultured with or without different concentrations of recombinant ovine IGF-I $(1,10$, $100 \mathrm{ng} \mathrm{ml}^{-1}$ ) or ovine LH (1 and $10 \mathrm{ng} \mathrm{ml}^{-1}$ ) and the interaction between human TNF- $\alpha\left(0.01\right.$ and $\left.10.0 \mathrm{ng} \mathrm{ml}^{-1}\right)$ and LH, IGF-I or a combination of both was assessed. In all experiments, the total incubation volume was $500 \mu \mathrm{l}$ per well. At the end of the incubation period, medium was collected and stored at $-20^{\circ} \mathrm{C}$ until the progesterone concentration was determined by radioimmunoassay.

At the end of all experiments, the final DNA content of the culture wells was determined and used to correct the progesterone production data, as the values of progesterone production are dependent on the number of cells in each well.

\section{Effect of macrophage-conditioned medium on progesterone production}

Granulosa cells from the largest and third largest follicles were incubated with different volumes (50, 100, 150, 200, 250 and $300 \mu$ per well) of HD11-conditioned media (MCMWLPS and MCMWOLPS) during 3, 24 and $48 \mathrm{~h}$ of culture to determine the time and concentration effects of the conditioned media on progesterone production. As for $\operatorname{rhTNF}-\alpha$, the effects were apparent after $48 \mathrm{~h}$ of incubation. Therefore, subsequent experiments to determine interactions with IGF-I and $\mathrm{LH}$ at different concentrations were conducted under $48 \mathrm{~h}$ incubations. Since conditioned media were prepared in medium containing $5 \%$ chicken serum, it was necessary to eliminate the effect of the serum in the serum-free set-up. Therefore, additional control incubations with similar volumes of medium containing $5 \%$ chicken serum only (that is medium not conditioned with HD11) were included. Similarly, a second set of control incubations was set up to correct for the effect of $5 \mu \mathrm{g}$ LPS $\mathrm{ml}^{-1}$ on granulosa cells. Granulosa cells were incubated in medium containing $5 \mu \mathrm{g}$ LPS $\mathrm{ml}^{-1}$ and 5\% chicken serum; this medium was not conditioned with HD11. The effects of both MCMWLPS and MCMWOLPS on progesterone production were corrected for the separate effects of chicken serum and LPS alone (that is medium not conditioned with HD11). The total incubation (a)

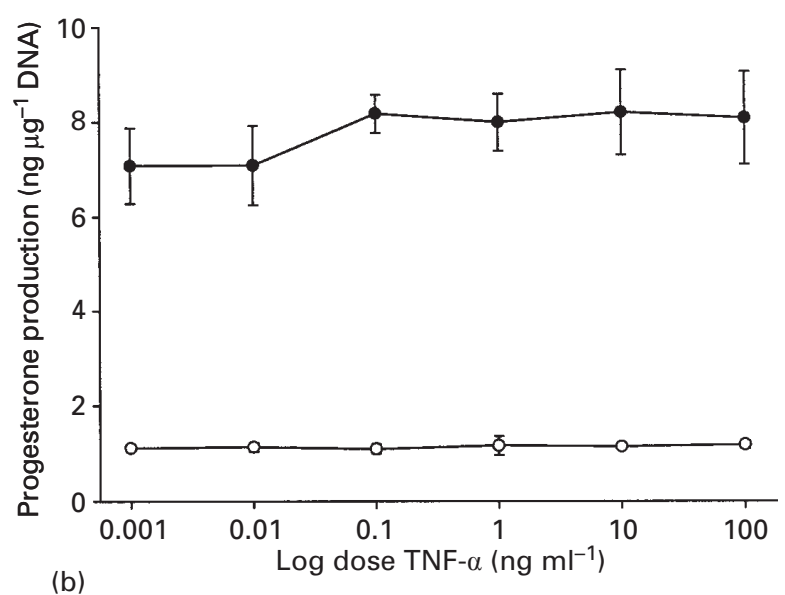

(b)

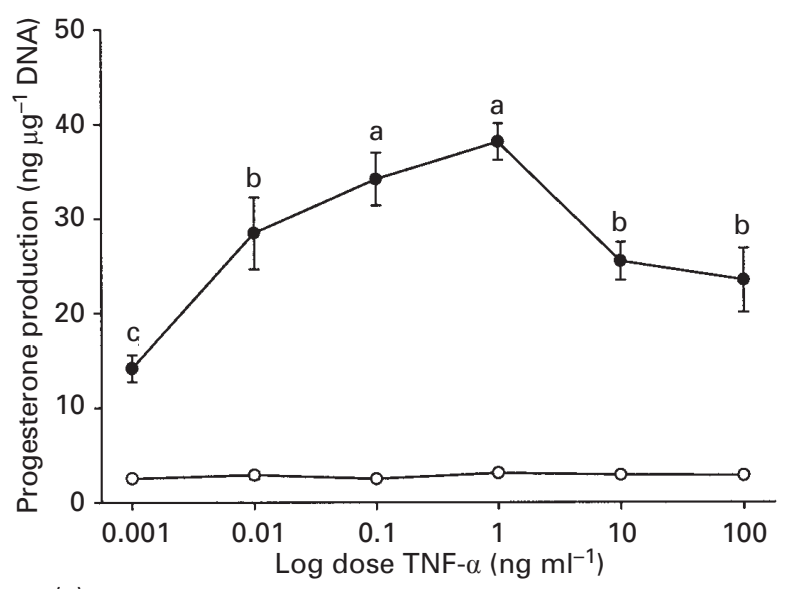

(c)

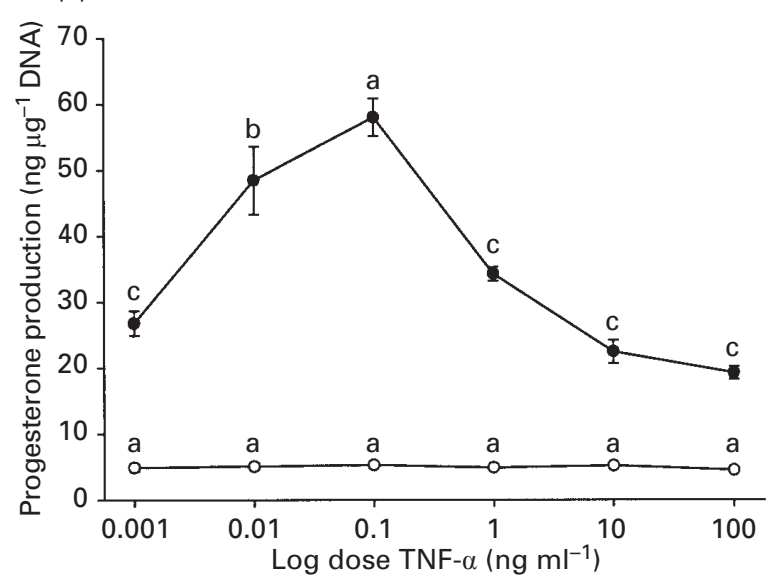

Fig. 2. Effects of dose of (0-100 $\left.\mathrm{ng} \mathrm{ml}^{-1}\right)$ and time of exposure (a) 3, (b) 24, (c) $48 \mathrm{~h}$ to recombinant human tumour necrosis factor $\alpha$ (rhTNF- $\alpha$ ) on progesterone production by chicken granulosa cells of the largest $(\bullet)$ and third largest $(\bigcirc)$ follicles cultured in serum-free medium. Data points represent means \pm SEM. Significant differences between doses within each type of follicle are represented by different letters $(P<0.05)$.

volume in all experiments was $500 \mu \mathrm{l}$ per well. Medium was collected at the end of experiments and stored at $-20^{\circ} \mathrm{C}$ until assayed for progesterone. The DNA content of wells was determined at the end of experiments. 


\section{Effects of TNF- $\alpha$ and macrophage-conditioned medium on granulosa cell DNA synthesis}

Granulosa cells from the largest and third largest follicles were cultured in serum-free medium for $72 \mathrm{~h}$ in the presence or absence of different concentrations of TNF- $\alpha(0-100 \mathrm{ng}$ $\mathrm{ml}^{-1}$ ) or increasing volumes of MCMWLPS (50-300 $\mu \mathrm{l}$ per well). Cultures containing medium that was not conditioned with macrophages, but contained LPS alone were included as controls. The influence of chicken serum in the conditioned medium was also determined and corrected for, as in the previous experiments. The effects of TNF- $\alpha$ ( 0.1 or $10.0 \mathrm{ng}$ $\mathrm{ml}^{-1}$ ) or the HD11-conditioned medium (100 or $250 \mu \mathrm{l}$ per well) on granulosa cell DNA synthesis stimulated by IGF-I (1 or $10 \mathrm{ng} \mathrm{ml}^{-1}$ ) or LH $\left(10 \mathrm{ng} \mathrm{ml}^{-1}\right)$ or IGF-I and LH were also determined. At the end of the experimental period cultures were washed and the DNA content of wells was determined to assess cell proliferation during the $72 \mathrm{~h}$ of culture in the presence of the test hormones and conditioned medium.

\section{Progesterone assay}

Progesterone concentration in the culture medium was determined by radioimmunoassay without extraction. Assay was conducted with a commercial kit (ICN Biomedicals Inc., Costa Mesa, CA). The crossreactivities of the antiserum in the kit with other ligands are $20 \alpha$-dihydroprogesterone $5.46 \%$, desoxycorticosterone $3.8 \%$ and $<1 \%$ for other steroids. The intra-assay and interassay coefficients of variation were $6.30 \%$ and $11.4 \%$, respectively.

\section{DNA assay}

Cultures for DNA determination were washed in pfHBSS. The cells were disaggregated with $200 \mu$ trypsin-EDTA (Boerhinger Mainheim) in TNE buffer $\left(10 \mathrm{mmol}\right.$ Tris $\mathrm{l}^{-1}$, 1 mmol EDTA $1^{-1}, 2$ mol $\mathrm{NaCl} \mathrm{l}^{-1}, \mathrm{pH}$ 7.4) followed by sonication. DNA in aliquots of the lysate was determined by the method of Labarca and Paigen (1980) using calf thymus DNA (Sigma) as standard and H33258 (bisbenzimide; Sigma) as fluorogen. The DNA was quantified on a TKO $100 \mathrm{mini}$ fluorometer (Hoeffer Scientific Instruments, San Francisco, CA).

\section{Statistical analysis}

Data presented are means \pm SEM of four experiments for each study and were analysed by ANOVA. Statistical differences were assessed by Duncan's multiple-range test (General Linear Models procedure, SAS Institute, 1985). $P$ values of $<0.05$ were considered statistically significant.

\section{Results}

\section{Effects of TNF- $\alpha$ on progesterone production by granulosa cells of developing follicles}

Human recombinant TNF- $\alpha$ significantly increased progesterone production by cultured granulosa cells of the largest follicle in a dose- and time-dependent manner (Fig. 2). Responsiveness of the granulosa cells from the largest follicle to TNF- $\alpha$ stimulation increased with incubation. Whereas granulosa cells of the largest follicle incubated with rhTNF- $\alpha$ for $3 \mathrm{~h}$ showed no significant increase in progesterone production after 24 and $48 \mathrm{~h}$ of incubation, rhTNF- $\alpha$ significantly increased progesterone production in a dosedependent manner. The maximum effective dose of rhTNF- $\alpha$ was 0.1 and $1.0 \mathrm{ng} \mathrm{ml}^{-1}$ for incubations of 48 and $24 \mathrm{~h}$, respectively. Higher doses of TNF- $\alpha$ significantly decreased progesterone production below that produced by the maximum effective dose. However, in the third largest follicle, TNF- $\alpha$ at all concentrations had no effect on progesterone production at 3,24 or $48 \mathrm{~h}$.

In granulosa cells of the largest and third largest follicles, rhTNF- $\alpha$ at $0.01 \mathrm{ng} \mathrm{ml}^{-1}$ increased progesterone production when induced by 1 or $10 \mathrm{ng} \mathrm{LH} \mathrm{ml}^{-1}$ but not by100 ng LH $\mathrm{ml}^{-1}$ (Fig. 3). However, $10 \mathrm{ng}$ rhTNF- $\alpha \mathrm{ml}^{-1}$ inhibited LHstimulated (10 or $100 \mathrm{ng} \mathrm{ml}^{-1}$ ) progesterone production. The effect of 0.01 or $10.0 \mathrm{ng}$ TNF- $\alpha \mathrm{ml}^{-1}$ on IGF-I- or LHstimulated progesterone production by granulosa cells of the largest and third largest follicles is shown (Fig. 4). When $0.01 \mathrm{ng} \mathrm{TNF}-\alpha \mathrm{ml}^{-1}$ alone or in combination with IGF-I at 1 or $10 \mathrm{ng} \mathrm{ml}^{-1}$ was added to the cultures of granulosa cells from the largest follicle, progesterone production increased significantly. Progesterone production, in the presence of a combination of LH $\left(10 \mathrm{ng} \mathrm{ml}^{-1}\right)$ and IGF-I $\left(10 \mathrm{ng} \mathrm{ml}^{-1}\right)$ was also significantly increased by $0.01 \mathrm{ng}$ TNF- $\alpha \mathrm{ml}^{-1}$ but not by $10.0 \mathrm{ng} \mathrm{ml}^{-1}$. Although TNF- $\alpha$ alone at $10 \mathrm{ng} \mathrm{ml}^{-1}$ increased basal progesterone production, at 1 and $10 \mathrm{ng} \mathrm{ml}^{-1}$ it inhibited IGF-I stimulated production. Similarly TNF- $\alpha$ inhibited the effect of $\mathrm{LH}$ alone or the combination of $\mathrm{LH}$ and IGF-I.

Whereas both 0.01 and $10.0 \mathrm{ng}$ TNF- $\alpha \mathrm{ml}^{-1}$ had no effect on basal progesterone production of granulosa cells from the third largest follicle, the lower dose $\left(0.01 \mathrm{ng} \mathrm{ml}^{-1}\right)$ significantly increased IGF-I stimulated progesterone production. The higher dose of TNF- $\alpha\left(10 \mathrm{ng} \mathrm{ml}^{-1}\right)$ had no effect on progesterone production stimulated by 1 ng IGF-I ml ${ }^{-1}$ but significantly inhibited the effect of $10 \mathrm{ng}$ IGF-I ml ${ }^{-1}$. TNF- $\alpha$ at $10 \mathrm{ng} \mathrm{ml}^{-1}$ also inhibited the combined effect of LH and IGF-I on progesterone production, but $0.01 \mathrm{ng}$ TNF-I ml-1 neither increased nor inhibited progesterone production.

\section{Effect of TNF- $\alpha$ on granulosa cell proliferation}

The addition of TNF- $\alpha$ alone at different concentrations (0.001-100.0 $\mathrm{ng} \mathrm{ml}^{-1}$ ) to cells cultured for $48 \mathrm{~h}$ had no effect on basal DNA synthesis in granulosa cells from the largest or third largest follicles (data not shown). However, when granulosa cells from the third largest follicle were cultured in the presence of IGF-I $\left(10 \mathrm{ng} \mathrm{ml}^{-1}\right)$, TNF- $\alpha$ at 0.1 or $10.0 \mathrm{ng} \mathrm{ml}^{-1}$ increased IGF-I stimulated DNA synthesis (Fig. 5). In the presence of IGF-I $\left(10 \mathrm{ng} \mathrm{ml}^{-1}\right)$ and LH $\left(10 \mathrm{ng} \mathrm{ml}^{-1}\right), 0.1 \mathrm{ng}$ TNF- $\alpha \mathrm{ml}^{-1}$ significantly increased the combined effect of LH and IGF-I on DNA synthesis. However, the addition of $10 \mathrm{ng}$ TNF- $\alpha \mathrm{ml}^{-1}$ inhibited this effect. In cultures of granulosa cells from the largest follicle, IGF-I and the combination of IGF-I and LH marginally increased DNA synthesis. TNF- $\alpha$ at 
(a)

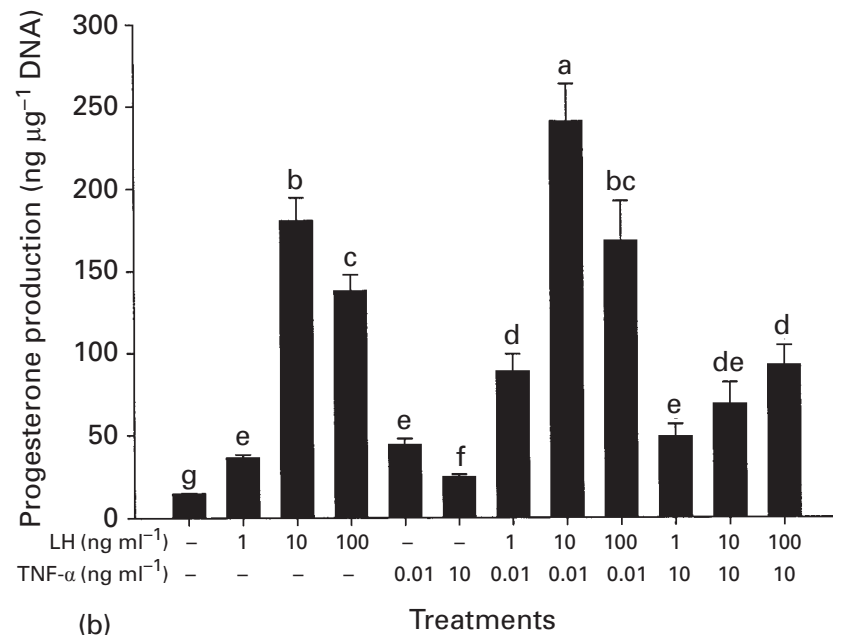

(b)

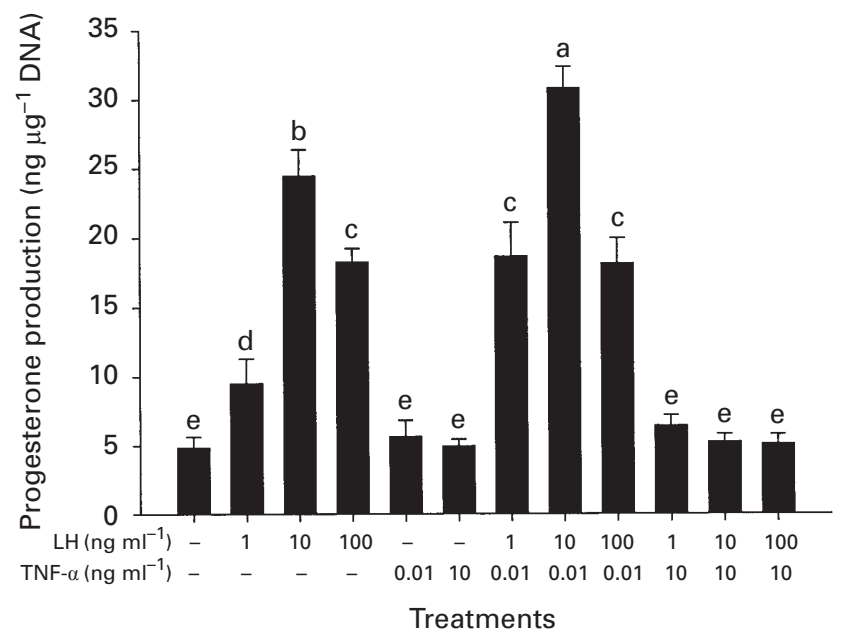

Fig. 3. Effects of recombinant human tumour necrosis factor $\alpha$ $($ rhTNF- $\alpha$ ) on LH-stimulated progesterone production by chicken granulosa cells of (a) the largest and (b) the third largest follicles cultured for $48 \mathrm{~h}$ in serum-free medium. Data points represent means \pm SEM. Significant differences between treatments within each type of follicle are represented by different letters $(P<0.05)$.

$0.1 \mathrm{ng} \mathrm{ml}^{-1}$ had no effect on either IGF-I stimulated DNA synthesis or on the effect of the combination of IGF-I and LH. Although $10 \mathrm{ng}$ TNF- $\alpha \mathrm{ml}^{-1}$ had no effect on IGF-I stimulated cell proliferation, it inhibited the effect of the combination of IGF-I and LH.

\section{Effect of macrophage-conditioned media on granulosa cell progesterone production}

HD11-conditioned media contained factors that modulated progesterone production by cultured granulosa cells (Fig. 6). These factors were present in both MCMWLPS and MCMWOLPS media. Addition of the media increased progesterone production by cultured granulosa cells from the largest follicle and this effect increased with increasing volume (50-300 $\mu \mathrm{l})$. However, both media had no effect on (a)

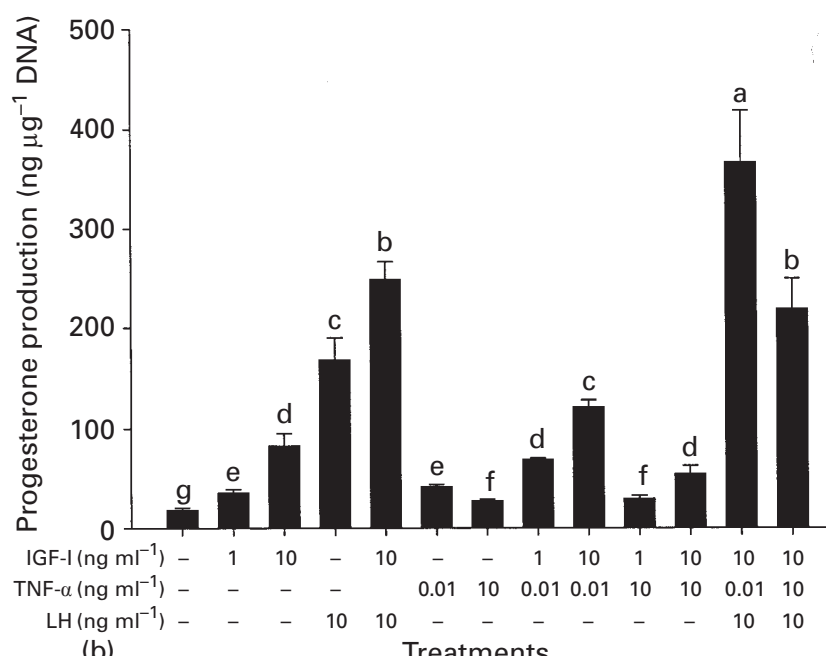

(b)

Treatments

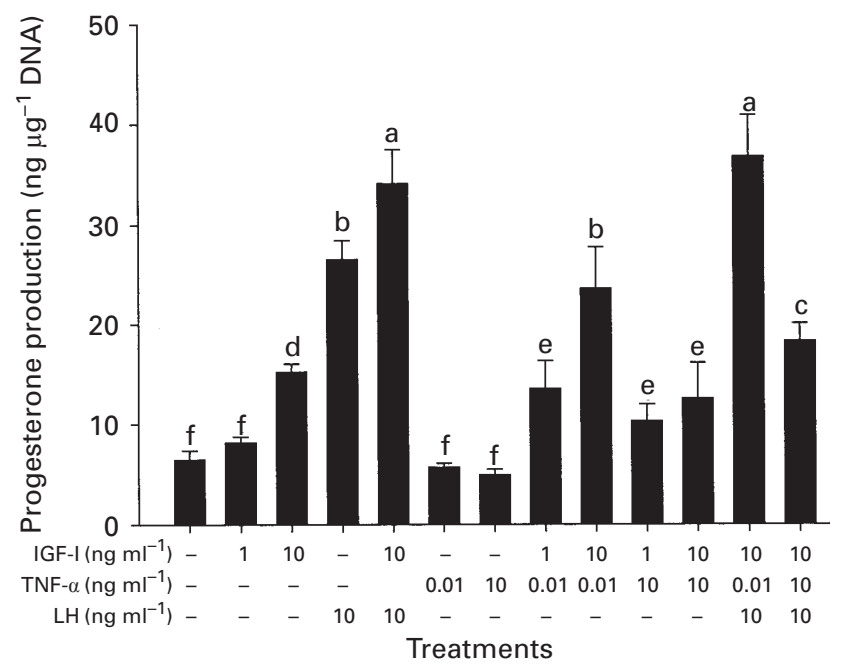

Fig. 4. Effects of different concentrations of recombinant human tumour necrosis factor $\alpha$ (rhTNF- $\alpha$ ), IGF-I, LH and their combinations on progesterone production by chicken granulosa cells of (a) the largest and (b) the third largest follicles cultured for $48 \mathrm{~h}$ in serum-free medium. Data represent means \pm SEM and were analysed by ANOVA and Duncan's multiple-range test. Significant differences between treatments are represented by different letters $(P<0.05)$.

progesterone production by granulosa cells of the third largest follicle.

The data show that medium from activated HD11 (MCMWLPS) significantly increased progesterone production in the granulosa cells from the largest follicle above that seen in medium from unactivated HD11 (MCMWOLPS). The data also show that this significant increase was not due to the presence of LPS in the medium, but a result of factors secreted by the macrophages due to LPS activation. The addition of LPS alone to granulosa cell cultures did not significantly increase progesterone production. The HD11 macrophage cell line produced TNF- $\alpha$ and the LPS activation significantly increased the secretion of TNF- $\alpha$ (Fig. 1).

The effect of two volumes of MCMWLPS, either alone or 
(a)
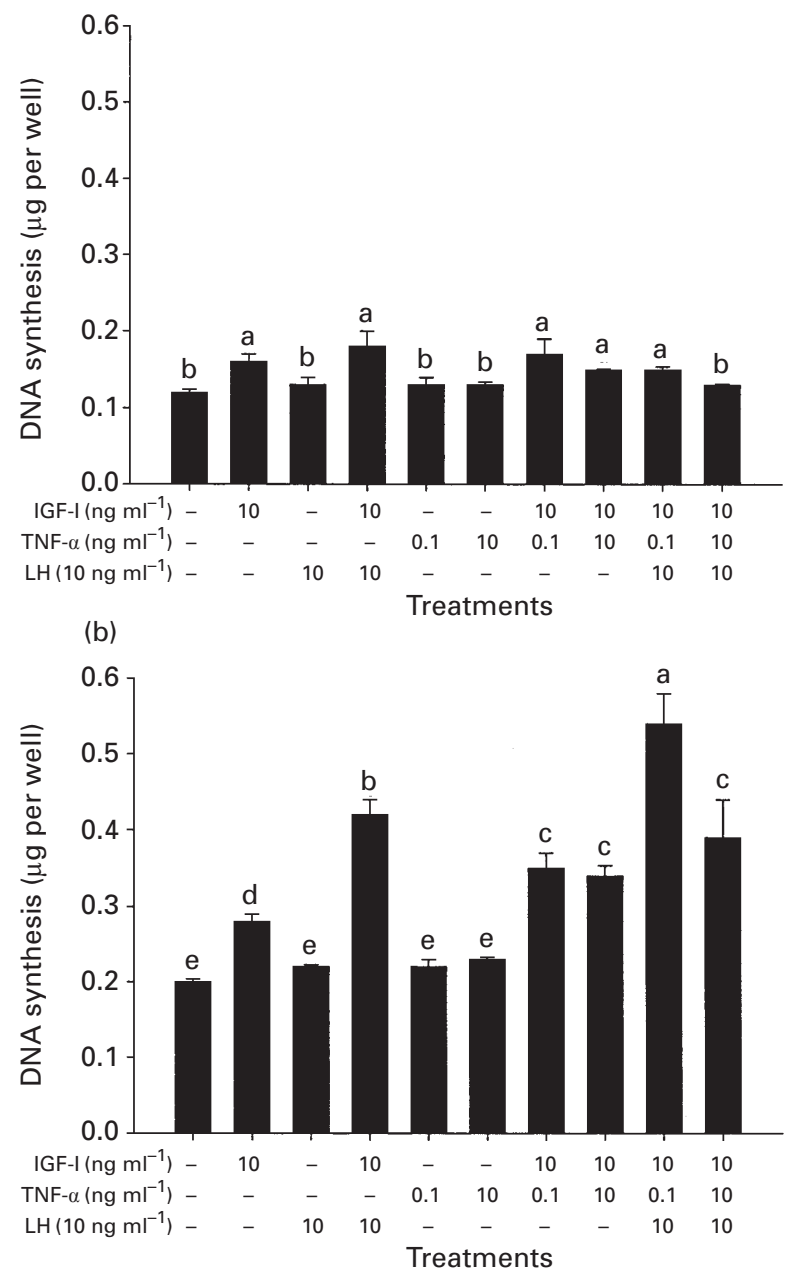

Fig. 5. Effects of different concentrations of recombinant human tumour necrosis factor $\alpha$ (rhTNF- $\alpha$ ), IGF-I, LH and their combinations on DNA synthesis by chicken granulosa cells of (a) the largest and (b) the third largest follicles cultured for $72 \mathrm{~h}$ in serum-free medium. Data represent means \pm SEM and were analysed by ANOVA and Duncan's multiple-range test. Statistical differences between treatments are represented by different letters $(P<0.05)$.

in combination with different doses of IGF-I or LH, on progesterone production by cultured granulosa cells from the largest and third largest follicles is shown (Fig. 7). Both volumes of the medium (100 and $250 \mu \mathrm{l})$ significantly increased progesterone production induced by $1 \mathrm{ng}$ IGF-I $\mathrm{ml}^{-1}$ in cultured granulosa cells from the largest follicle. However, in the presence of $10 \mathrm{ng}$ IGF-I ml-1 the larger volume $(250 \mu \mathrm{l})$ of medium did not alter progesterone production above that induced by IGF-I. The combination of both IGF-I $\left(10 \mathrm{ng} \mathrm{ml}^{-1}\right)$ and LH $\left(10 \mathrm{ng} \mathrm{ml}^{-1}\right)$ significantly increased the production of progesterone by granulosa cells and the addition of $100 \mu \mathrm{l}$ conditioned medium increased progesterone production further. However, the addition of the larger volume $(250 \mu \mathrm{l})$ of MCMWLPS did not significantly alter the effect IGF-I with LH.

In granulosa cells from the third largest follicle, both IGF-I and LH increased progesterone production, whereas (a)
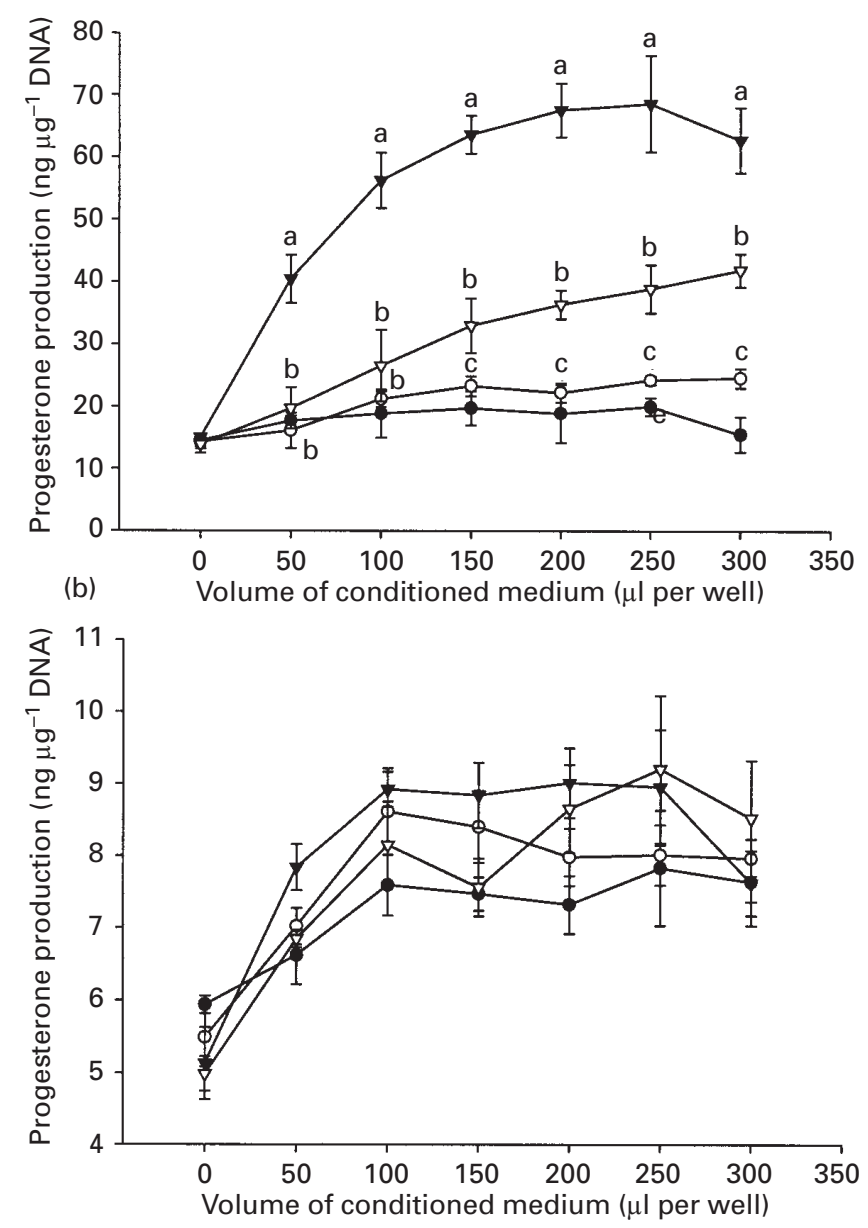

Fig. 6. Effects of conditioned medium from lipopolysaccharide (LPS)-activated $(\boldsymbol{\nabla})$, or unactivated HD11 macrophages $(\nabla)$, or LPS alone $(\bigcirc)$ on progesterone production by chicken granulosa cells from (a) the largest and (b) the third largest follicles cultured for $48 \mathrm{~h}$ in M199; - control (medium with chicken serum only). Data represent means \pm SEM. Significant differences between the effects of different media at similar volumes are represented by different letters $(P<0.05)$.

MCMWLPS had no effect. Both 100 and $250 \mu \mathrm{l}$ of MCMWLPS also had no effect on progesterone production stimulated by $1 \mathrm{ng}$ IGF-I ml-1, but both volumes of MCMWLPS inhibited progesterone production stimulated by $10 \mathrm{ng}$ IGF-I ml-1. IGFI-enhanced LH-stimulated progesterone production was also significantly decreased by both volumes of MCMWLPS.

\section{Effect of macrophage-conditioned medium on granulosa cell proliferation}

The addition of MCMWLPS or MCMWOLPS at increasing volumes (50-300 $\mu \mathrm{l})$ to cultures of granulosa cells from the largest or third largest follicles did not affect the basal DNA content of the culture wells after $72 \mathrm{~h}$ of culture (Fig. 8). The effect of two concentrations (100 and $250 \mu \mathrm{l}$ ) of MCMWLPS alone or in combination with IGF-I or LH on cultured 

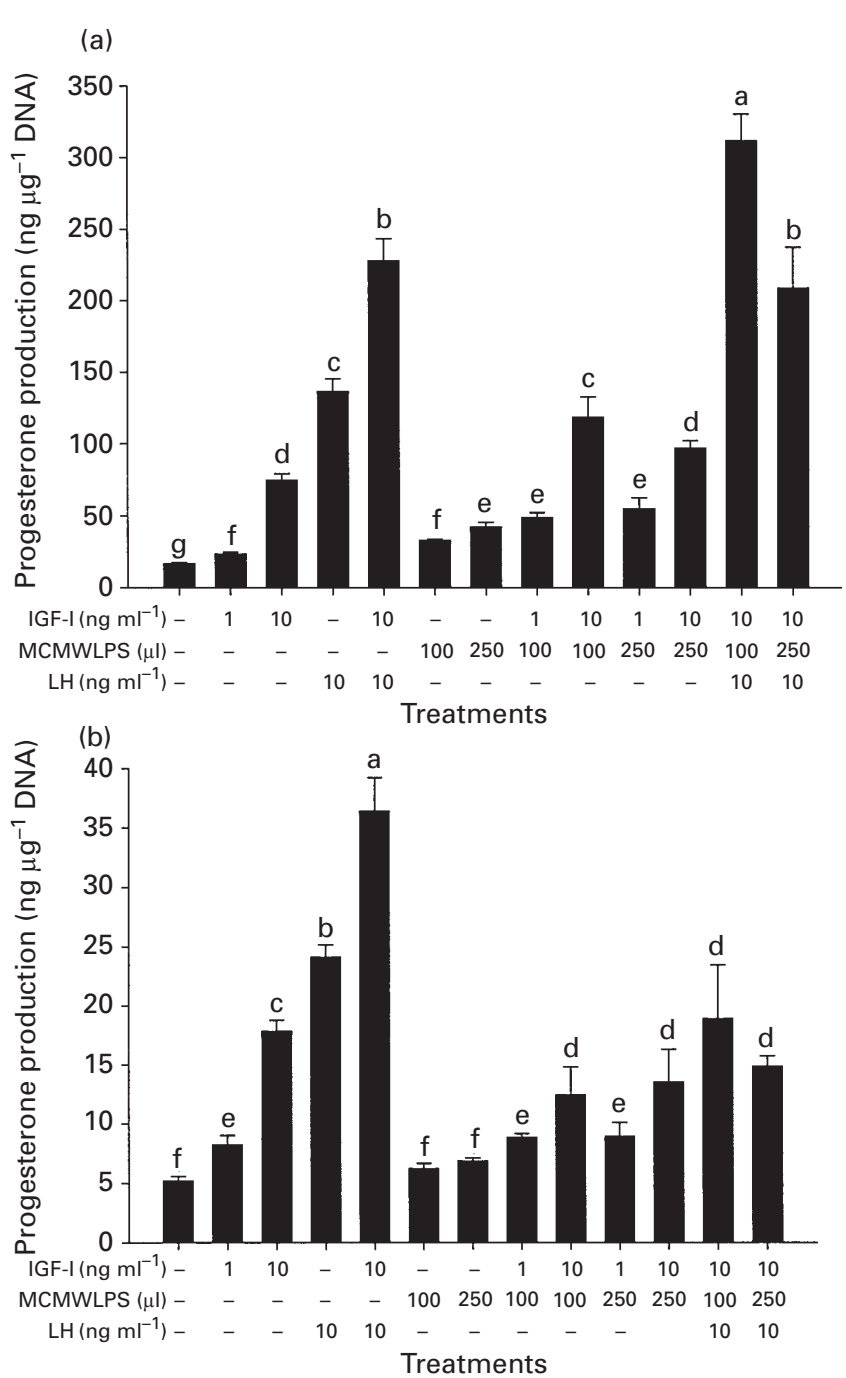

Fig. 7. Progesterone production by chicken granulosa cells from (a) the largest and (b) the third largest follicles cultured for $48 \mathrm{~h}$ in response to stimulation with different concentrations of medium conditioned with macrophages with lipopolysaccharide (MCMWLPS), IGF-I, LH and their combinations. Data represent means \pm SEM. Significant differences between treatments are represented by different letters $(P<0.05)$.

granulosa cells from the largest and third largest follicles is shown (Fig. 9). In the cultures of cells from both types of follicle, both volumes of MCMWLPS had no effect on basal DNA synthesis. However, DNA synthesis stimulated by $10 \mathrm{ng}$ IGF-I ml-1 was increased significantly in the granulosa cells from the third largest follicle by the addition of 100 or $250 \mu \mathrm{l}$ of the medium. When cells were cultured in the presence of both IGF-I (10 $\left.\mathrm{ng} \mathrm{ml}^{-1}\right)$ and LH $\left(10 \mathrm{ng} \mathrm{ml}^{-1}\right)$, the smaller volume $(100 \mu \mathrm{l})$ of MCMWLPS tended to increase the combined effect, but the larger volume did not.

In the granulosa cells from the largest follicle, IGF-I (10 $\left.\mathrm{ng} \mathrm{ml}^{-1}\right)$ alone and in combination with $\mathrm{LH}\left(10 \mathrm{ng} \mathrm{ml}^{-1}\right)$ increased DNA synthesis significantly. The addition of either 100 or $250 \mu \mathrm{l}$ MCMWLPS had no effect on basal DNA synthesis, or on DNA synthesis stimulated by IGF-I alone or combination with LH.

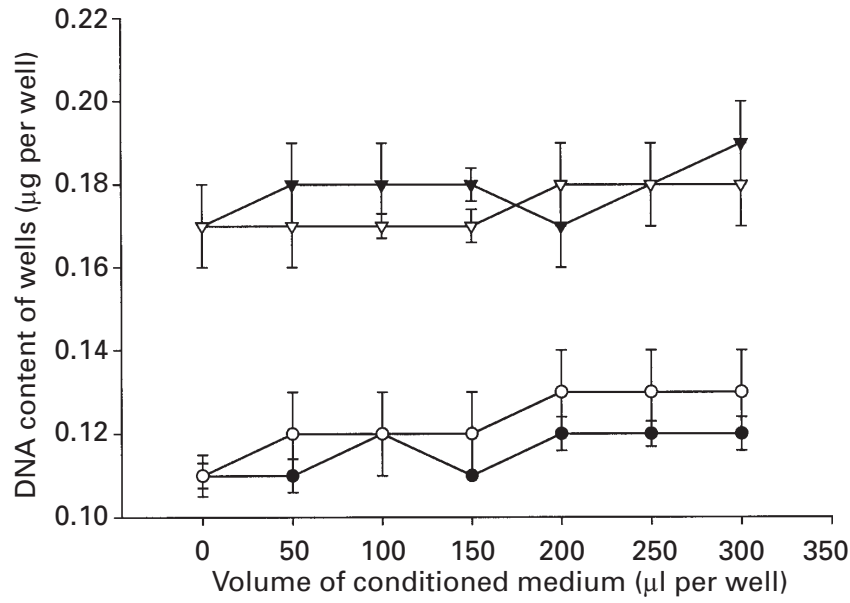

Fig. 8. Effects of increasing volumes of medium conditioned with macrophages with (MCMWLPS) or without (MCMWOLPS) lipopolysaccharide on DNA synthesis by chicken granulosa cells from the largest or third largest follicles. - MCMWOLPS and granulosa cells from the largest follicle; $\bigcirc$, MCMWLPS and granulosa cells from the largest follicle; $\mathbf{\nabla}$, MCMWOLPS and granulosa cells from the third largest follicle; $\nabla$, MCMWLPS and granulosa cells from the third largest follicle. Data represent means \pm SEM. No significant difference was found between the two treatments, within follicles, for all volumes of the media.

\section{Discussion}

This study demonstrates that TNF- $\alpha$ has modulatory effects on chicken granulosa cell progesterone production and proliferation, and may form an intergral part of the mechanism that regulates follicular growth and differentiation of follicles in the avian ovary. Furthermore, macrophages present in the ovary may be involved in the production of cytokines that take part in this regulatory mechanism. The data indicate that TNF- $\alpha$ can be either stimulatory or inhibitory depending on the concentration, the effect of other hormones or growth factors, the time of exposure and the stage of follicular maturation. Granulosa cells of developing follicles showed differential responsiveness to TNF- $\alpha$. TNF- $\alpha$ regulated basal progesterone production by stimulating production in the largest follicle destined to ovulate next, but did not affect the third largest and thus less mature follicle. TNF- $\alpha$ also modulated the responsiveness of granulosa cells to the effects of IGF-I with or without LH, both of which promote growth and differentiation. At low concentrations, TNF- $\alpha$ tended to increase the effects of IGF-I, with or without $\mathrm{LH}$, on progesterone production by granulosa cells of the largest and third largest follicles, but at high concentrations TNF- $\alpha$ inhibited the hormone-stimulated production of progesterone in these cells. TNF- $\alpha$ increased proliferation promoted by IGF-I alone or in combination with LH in granulosa cells from the third largest follicle but not in the those from the largest follicle. Furthermore, TNF- $\alpha$ tended to regulate the magnitude of the combined effect of IGF-I and $\mathrm{LH}$ on cell proliferation in the third largest follicle by reducing the stimulatory effect of high doses of both.

Conditioned medium from LPS-activated HD11 macrophages mimicked the effects of TNF- $\alpha$ on granulosa cell progesterone production and proliferation. These effects 


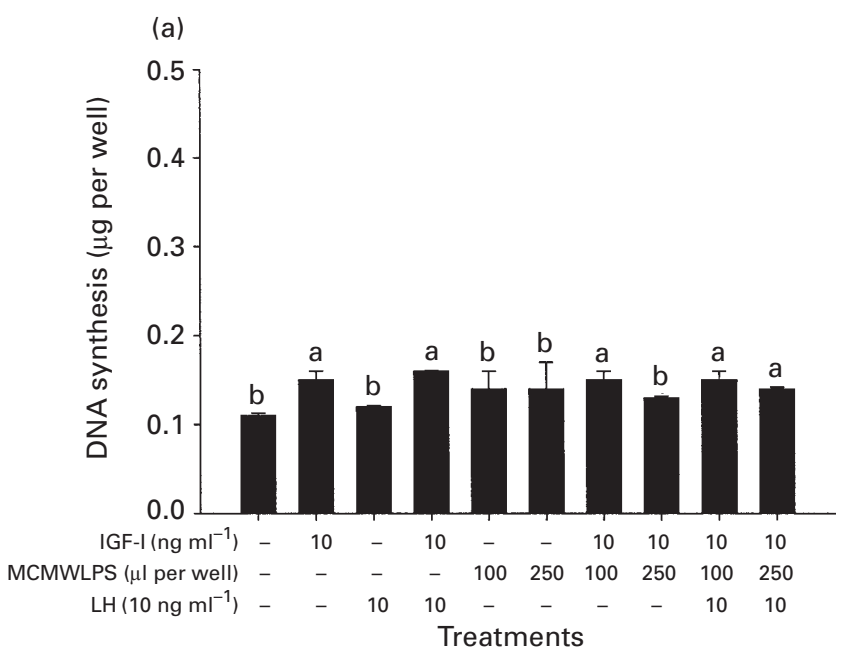

(b)

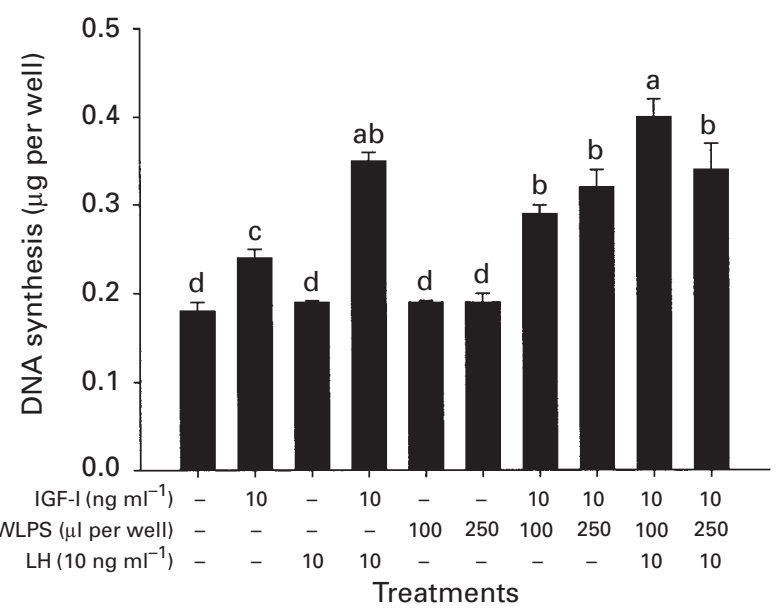

Fig. 9. DNA synthesis by medium conditioned with macrophages with lipopolysaccharide (MCMWLPS) cultured for $48 \mathrm{~h}$ in response to stimulation with different concentrations of IGF-I, LH and their combinations. Data represent means \pm SEM. Significant differences between treatments are represented by different letters $(P<0.05)$.

may not be due to the effect of TNF- $\alpha$ in the conditioned medium as other cytokines may be present, but the results indicate that TNF- $\alpha$ has a substantial effect. Thus, macrophages in chicken follicles may be instrumental in the provision of TNF- $\alpha$ to modulate granulosa cell progesterone production and cell proliferation. This is further evidence that chicken TNF- $\alpha$ may be as effective as mammalian TNF$\alpha$ in the modulation of ovarian functions.

A marked effect of both rhTNF- $\alpha$ and MCMWLPS was the significant inhibition of progesterone production stimulated by IGF-I alone or in combination with LH in granulosa cells from the third largest follicle, whereas progesterone production increased in granulosa cells from the largest follicle. rhTNF- $\alpha$ increased IGF-I stimulated cell proliferation in the third largest follicle but inhibited growth promoted by the combined effects of high concentrations of IGF-I and LH. This effect may be one of the mechanisms involved in maintaining the hierarchy of the follicles such that immature follicles continue to grow and differentiate at a steady rate under the influence of IGF-I and gonadotrophins. At the same time, TNF- $\alpha$ enhances the activities of IGF-I and LH on progesterone production in the granulosa cells of the largest follicle such that the cells of the most mature follicles produce sufficient concentrations of progesterone for feedback mechanisms to increase LH production for ovulation.

TNF- $\alpha$ regulates growth and differentiation of follicular cells in a paracrine and autocrine manner in mammalian ovaries, and macrophages, leucocytes, granulosa and theca cells are sources of TNF- $\alpha$ within the ovary (Adashi et al., 1989; Roby and Terranova, 1989; Zolti et al., 1990; Veldhuis et al., 1991; Spicer, 1998; Montgomery Rice et al., 1998, 1999; Spaczynski et al., 1999; Zhao et al., 1998). These reports indicate that TNF- $\alpha$ has a diverse spectrum of biological activity. TNF- $\alpha$ can either stimulate cell proliferation or differentiation, induce apoptotic cell death or can remain without effect (Wang et al., 1992; Yan et al., 1993; Karakji and Tsang, 1995; Kaipia et al., 1996; Spaczynski et al., 1999). Studies have shown that TNF- $\alpha$ inhibits IGF-I and gonadotrophin induced production of progesterone, oestrogens and androgens from the granulosa or theca of the ovary (Spicer and Alpizer, 1994; Terranova et al., 1995; Spicer, 1998; Montgomery Rice et al., 1999). Inhibitory and stimulatory effects and the type of response elicited by TNF- $\alpha$ may depend on the species, the type of cell and the stage of follicular development (Roby and Terranova, 1988; Montgomery Rice et al., 1998).

Studies on the response of chicken granulosa cells to TNF$\alpha$ stimulation have been inconclusive. Bryan et al. (1997) showed an inconsistent inhibitory effect of $5 \mathrm{ng} \mathrm{rhTNF}-\alpha \mathrm{ml}^{-1}$ on basal progesterone production by freshly prepared granulosa cells from the largest and the third largest follicles of two lines of chickens, and reported that $250 \mathrm{ng} \mathrm{TNF}-\alpha \mathrm{ml}^{-1}$ had no effect or was stimulatory. However, Bryan et al. (1997) did not study the effects of IGF-I or gonadotrophins. Soboloff et al. (1999) did not find any effect of different doses (1-50 ng $\mathrm{ml}^{-1}$ ) of rhTNF- $\alpha$ on basal or LH-stimulated progesterone production by granulosa cells of White Leghorn hens. However, these studies were conducted under short-term $3 \mathrm{~h}$ incubations. In a time course experiment using cultured whole rat follicles, Roby and Terranova (1988) demonstrated that a consistent effect of TNF- $\alpha$ could not be seen until after $24 \mathrm{~h}$ of culture in vitro. In the present study, after establishing granulosa cells in culture for $48 \mathrm{~h}$ and adding TNF- $\alpha$ for $3 \mathrm{~h}$, no significant change in progesterone concentration was observed. Only after $24 \mathrm{~h}$ incubation with TNF- $\alpha$ was a significant increase in progesterone concentration detected. Onagbesan and Peddie (1995) demonstrated that IGF-I alone does not affect progesterone production until after $24 \mathrm{~h}$ in culture. Therefore, the discrepancies between other reports and the effects recorded with TNF- $\alpha$ in the present study may be due to differences in experimental approaches.

The results of the present study are in agreement with those reported for mammalian studies in that granulosa cells from follicles at different stages of development responded in a different way to TNF- $\alpha$ alone or in combination with either LH or IGF-I or both. Montgomery Rice et al. (1998) found differential effects of TNF- $\alpha$ alone or with FSH, on progesterone or oestradiol production by cultured human granulosa cells obtained from small and large follicles during the follicular or luteal phase of the menstrual cycle. Spicer 
and Alpizer (1994) also showed differential responsiveness to TNF- $\alpha$ between granulosa cells of large and small follicles of the bovine ovary and cells of small follicles responded better than those from large follicles.

Chicken macrophages secrete cytokines, mainly TNF- $\alpha$ and interleukins, as do mammalian macrophages and leucocytes (Bombara and Taylor, 1991; Qureshi and Miller, 1991; Qureshi et al., 1993; Cieszynski et al., 1999). The current study confirmed that TNF- $\alpha$ is secreted into the conditioned medium of activated and unactivated HD11 macrophages. The activity of the conditioned medium indicates that the activity of TNF- $\alpha$, possibly with other cytokines, is involved in the regulation of chicken granulosa cell progesterone production and cell proliferation. By co-culturing peritoneal macrophages with rat granulosa cells, Shakil and Whitehead (1994) demonstrated that secretions from the macrophages that contained predominantly TNF- $\alpha$ and interleukin-1 $\beta$ modulated progesterone production by the ovarian cells. The response of the granulosa cells was dependent on the number of macrophages in the culture, whether they were pre-treated with LPS and in the presence or absence of gonadotrophins. Recently, Barua et al. $(1998 \mathrm{a}, \mathrm{b})$ showed that chicken follicles contained a population of macrophages in the theca compartment but the macrophages were not present in the granulosa. This population of macrophages increased with follicular maturation up to the stage of the third largest follicle, but no further increase was observed until ovulation. The fact that MCMWLPS and MCMWOLPS induce changes in progesterone production and cell proliferation indicates that, apart from the immune and phagocytic functions of macrophages, these cells may also be involved in the regulation of the normal growth and differentiation of follicles in the chicken ovary. Macrophages found in the theca may produce TNF- $\alpha$, which would exert paracrine effects on the granulosa or theca cells. The relatively large number of macrophages found in the third largest follicle compared with large follicles (in terms of size to the number of macrophages) may support the hypothesis that the function of the macrophages is to inhibit differentiation in small follicles, thereby preventing premature differentiation of future ovulatory follicles and maintaining the hierarchy.

In conclusion, this study has demonstrated that TNF- $\alpha$ may be involved in the maintenance of normal follicle development and differentiation in the chicken ovary and that chicken ovarian macrophages may be a source of TNF- $\alpha$ for this purpose.

The authors are grateful to G. Nackaerts and C. Borgers for their technical support.

\section{References}

Acosta TJ, Miyamoto A, Ozawa T, Wijayagunawardane MP and Sato K (1998) Local release of steroid hormones, prostaglandin $\mathrm{E}_{2}$ and endothelin-1 from bovine mature follicles in vitro; effects of luteinizing hormone, endothelin-1 and cytokines Biology of Reproduction 59 437-443

Adashi EY (1990) The potential relevance of cytokines to ovarian physiology: the emergent role of resident ovarian cells of the white blood cell series Endocrine Reviews 11 454-464

Adashi EY, Resnick CE, Croft CS and Payne DW (1989) Tumor necrosis alpha inhibits gonadotropin hormonal action in nontransformed ovarian granulosa cells. A modulatory noncytotoxic property Journal of Biological Chemistry 26411 591-11 597

Andreani CL, Payne DW, Packman JN, Resnick CE, Hurwitz A and Adashi EY (1991) Cytokine-mediated regulation of ovarian function. Tumor necrosis factor alpha inhibits gonadotropin-supported ovarian androgen biosynthesis Journal of Biological Chemistry 266 6761-6766

Bagavandoss P, Kunkel SL, Wiggins RC and Keyes PC (1988) Tumor necrosis factor- $\alpha$ (TNF- $\alpha)$ production and localization of macrophages and $\mathrm{T}$ lymphocytes in the rabbit corpus luteum Endocrinology 122 1185-1187

Barua A, Yoshimura Y and Tamura T (1998a) Localization of macrophages in the ovarian follicles during the follicular growth and postovulatory regression in chickens (Gallus domesticus) Poultry Science 77 1417-1421

Barua A, Yoshimura Y and Tamura T (1998b) The effects of age and sex steroids on the macrophage population in the ovary of the chicken, Gallus domesticus. Journal of Reproduction and Fertility 114 253-258

Beug H, von Kirchbach A, Doderlein G, Conscience JF and Graf T (1979) Chicken hematopoietic cells transformed by seven strains of defective avian leukemia viruses display three distinct phenotypes of differentiation Cell 18 375-390

Bombara CJ and Taylor RL (1991) Signal transduction events in chicken interleukin-1 production Poultry Science 70 1372-1380

Bryan MA, Grizzle JM, Saxton AM, Siegel PB and Dunnington EA (1997) Effects of tumor necrosis factor- $\alpha$ on progesterone production by granulosa cells in laying hens of different genetic lines Domestic Animal Endocrinology 14 161-169

Cieszynski JA, Qureshi MA and Taylor RL (1999) Calcium dependency of interleukin-1 secretion by a chicken macrophage cell line Poultry Science 78 70-74

Gilbert AB, Evans AY, Perry MM and Davidson MH (1977) A method for separating the granulosa, the basal lamina and the theca of the preovulatory ovarian follicle of the domestic fowl (Gallus domesticus) Journal of Reproduction and Fertility 50 179-181

Kaipia A, Chun SY, Eisenhauer K and Hsueh AJ (1996) Tumor necrosis factor-alpha and its second messenger, ceramide, stimulate apoptosis in cultured ovarian follicles Endocrinology 137 4864-4870

Karakji EG and Tsang BK (1995) Tumor necrosis factor alpha inhibits rat granulosa cell plasminogen activity in vitro during follicular development Biology of Reproduction $\mathbf{5 2}$ 745-752

Kondo H, Marou T and Mochizuki M (1995) Immunohistochemical evidence for the presence of tumor necrosis factor- $\alpha$ in the infant and adult ovary Endocrine Journal 42 771-780

Labarca C and Paigen K (1980) A simple, rapid and sensitive DNA assay procedure Analytical Chemistry 102 344-352

Montgomery Rice V, Limback SD, Roby KF and Terranova PF (1998) Differential responses of granulosa cells from small and large follicles to follicle stimulating hormone (FSH) during the menstrual cycle and acyclicity: effects of tumor necrosis factor-alpha Human Reproduction 13 1285-1291

Montgomery Rice V, Limback SD, Roby KF and Terranova PF (1999) Tumor necrosis factor alpha inhibition of follicle-stimulating hormone-induced granulosa cell oestradiol secretion in the human does not involve reduction of cAMP secretion but inhibition at post-cAMP site(s) Endocrine 10 19-23

Onagbesan OM and Peddie MJ (1995) Effects of insulin-like growth factor-I and interactions with transforming growth factor- $\alpha$ and LH on proliferation of chicken granulosa cells and progesterone production Journal of Reproduction and Fertility 104 259-265

Peddie MJ, Onagbesan OM and Williams J (1994) Chicken granulosa cell proliferation and progesterone production: effect of EGF and thecal secretions General and Comparative Endocrinology 94 341-356

Qureshi MA and Miller L (1991) Signal reqiurements for the acquisition of tumoricidal competence by chicken peritoneal macrophages Poultry Science 70 530-538

Qureshi MA, Pettite JN, Laster SM and Dietert RR (1993) Avian macrophages: contribution to cellular microenvironment and changes in effector functions following activation Poultry Science 72 1280-1284

Roby KF and Terranova PF (1988) Tumor necrosis factor alpha alters follicular steroidogenesis in vitro. Endocrinology 123 2952-2954

Roby KF and Terranova PF (1989) Localization of tumor necrosis factor (TNF) in rat and bovine ovary using immunocytochemistry and cell blot: evidence for granulosa production. In Growth Factors and the Ovary pp 273-278 Ed. AN Hirshfield. Plenum Press, New York

Roby KF, Weed J, Lyles R and Terranova PF (1990) Immunological evidence 
for a human ovarian tumor necrosis factor- $\alpha$ Journal of Clinical Endocrinology and Metabolism $\mathbf{7 1}$ 1096-1102

SAS (1985) SAS/STAT Guide for Personal Computers Version 6, SAS Institute Inc., Cary, NC

Shakil T and Whitehead SA (1994) Inhibitory action of peritoneal macrophages on progesterone secretion from co-cultured rat granulosa cells Biology of Reproduction 50 1183-1189

Shaw DW and Britt JH (1995) Concentrations of tumor necrosis factor- $\alpha$ and progesterone within the bovine corpus luteum sampled by continuous flow microdialysis during luteolysis in vivo. Biology of Reproduction 53 847-854

Soboloff J, Desilets M and Tsang BK (1995) Influence of tumor necrosis factor alpha on intracellular $\mathrm{Ca}^{2+}$ in hen granulosa cell in vitro during follicular development Biology of Reproduction 53 546-552

Soboloff J, Sorisky A, Desilets M and Tsang BK (1999) Acyl chain lengthspecific ceramide-induced changes in intracellular $\mathrm{Ca}^{2+}$ concentration and progesterone production are not regulated by tumor necrosis factor $\alpha$ in hen granulosa cells Biology of Reproduction 60 262-271

Spaczynski RZ, Arici A and Deluba AJ (1999) Tumor necrosis factor $\alpha$ stimulates proliferation of rat ovarian theca-interstitial cells Biology of Reproduction 61 993-998

Spicer LJ (1998) Tumor necrosis factor- $\alpha$ (TNF- $\alpha$ ) inhibits steroidogenesis of bovine ovarian granulosa and theca cells in vitro. Endocrine 8109-115

Spicer LJ and Alpizar E (1994) Effects of cytokines on FSH-induced estradiol production by bovine granulosa cells in vitro: dependence on size of follicle Domestic Animal Endocrinology 11 25-34

Terranova PF, Hunter VJ, Roby KF and Hunt JS (1995) Tumor necrosis factor alpha in the female reproductive tract Proceedings of the Society for Experimental Biology and Medicine 209 325-342

Veldhuis JD, Garmey JC, Urban RJ, Demers LM and Aggarwal BB (1991) Ovarian actions of tumor necrosis factor-alpha (TNF-alpha): pleiotropic effects of TNF-alpha on differentiated functions of untransformed swine granulosa cells Endocrinology 129 641-648
Wang LJ, Brannstrom M, Robertson SA and Norman RJ (1992) Tumor necrosis factor alpha in the human ovary; presence in follicular fluid and effects on cell proliferation and prostaglandin production Fertility and Sterility 58 934-940

Witty JP, Bridgham JT and Johnson AL (1996) Induction of apoptotic cell death in hen granulosa cells by ceramide Endocrinology 137 5269-5277

Wuttke W, Jarry H, Pitzel L, Knoke I and Spiess S (1993) Luteotrophic and luteolytic actions of ovarian peptides Human Reproduction 8141-146

Yan Z, Hunter V, Weed J, Hutchison S, Lyle R and Terranova P (1993) Tumor necrosis factor-alpha alters steroidogenesis and stimulates proliferation of human ovarian granulosa cells in vitro. Fertility and Sterility 59 332-338

Zachow RJ and Terranova PF (1993) Involvement of protein kinase C and protein tyrosine kinase pathways in tumor necrosis factor-alpha-induced clustering of ovarian theca-interstitial cells Molecular Cell Endocrinology 97 $37-49$

Zachow RJ and Terranova PF (1994) The effects of tumor necrosis factor- $\alpha$ on luteinizing hormone (LH)/insulin-like growth factor-I (IGF-I) regulated androstenedione biosynthesis and IGF-I directed LH receptor number in cultured ovarian theca-interstitial cells Endocrine 2 1145-1150

Zachow RJ, Tash JS and Terranova PF (1993) Tumor necrosis factor-alpha attenuation of luteinizing hormone-stimulated androstenedione production by ovarian theca-interstitial cells; inhibition at loci within the adenosine 3',5'-monophosphate-dependent signalling pathway Endocrinology 133 2269-2276

Zhao Y, Burbach JA, Roby KF, Terranova PF and Brannian JD (1998) Macrophages are the major source of tumor necrosis factor $\alpha$ in the porcine corpus luteum Biology of Reproduction 59 1385-1391

Zolti M, Meirom R, Shemesh M, Wollach D, Mashiach S, Shore L and Rafael ZB (1990) Granulosa cell as a source and target organ for tumor necrosis factor-alpha FEBS Letters 261 253-255 